\title{
Palaeoenvironmental interpretation of Late Pleistocene-Holocene morphosedimentary record in the Valsalada saline wetlands (Central Ebro basin, NE Spain)
}

\author{
Carlos Sancho ${ }^{\mathrm{a}}$, Arsenio Muñoz ${ }^{\mathrm{a}}$, Penélope González-Sampériz ${ }^{\mathrm{b}}$ and María Cinta Osácar ${ }^{\mathrm{a}}$ \\ ${ }^{a}$ Ciencias de la Tierra, Universidad de Zaragoza, Pedro Cerbuna 12, 50009 Zaragoza, Spain \\ ${ }^{\mathrm{b}}$ Procesos Geoambientales y Cambio Global, Instituto Pirenaico de Ecología, CSIC, Avenida \\ Montañana 1005, 50059 Zaragoza, Spain
}

\begin{abstract}
This work presents a palaeoenvironmental interpretation of the Upper Pleistocene-Holocene sedimentary sequence recorded in the Valsalada saline wetland system (Monegros, Central Ebro Basin). This morphosedimentary system developed on karstified, gypsiferous bedrock and was mainly fed by local saline groundwater. Based on geomorphological, sedimentological, palynological and radiocarbon data, three depositional units have been differentiated: 1) a lacustrine unit, which accumulated under cold/cool and humid environmental conditions at 41-40 kyr cal BP, 2) a fluvial unit that was deposited under arid climatic conditions with cold episodic periods from 14 to $3.5 \mathrm{kyr}$ cal BP, and 3) an alluvial slope unit associated with arid climate with human influence during the Late Roman Period (1.5 kyr cal BP). The morphosedimentary evolution of the Valsalada system is strongly influenced by the geomorphic setting (small catchment with karstic depressions and low gradient slopes on gypsum), the hydrological availability (runoff and groundwater discharges) related to climate variability during the Late Pleistocene-Holocene, and the human activities developed in the area during historical times. The response of the Valsalada system displays a low sensitivity to short term climatic changes but responds to major long-term climatic conditions, improving the regional paleoenvironmental picture of the Late Quaternary in NE Spain.
\end{abstract}

Key words: lacustrine/fluvial/alluvial records, saline wetlands, environmental change, Upper Pleistocene-Holocene, Central Ebro basin.

\section{Introduction}

The Ebro Basin, the northernmost semiarid region in Europe, is an area with high sensitivity to environmental change that contains excellent morphosedimentary records in response to Quaternary climate oscillations. The paleoenvironmental history of this area during the Late Pleistocene and Holocene has been gradually reconstructed during the last decades from fluvial (Fuller et al., 1998; Macklin et al., 2002; Thorndycraft and Benito, 2006; Lewis et al., 2009), lacustrine (Valero-Garcés et al., 2000a, 2000b, 2004; González-Sampériz et al., 2005; 2008; Morellón et al., 2008, 2009), slope (Gutiérrez and Peña, 1998; Gutiérrez et al., 1998, 2006; Valero-Garcés et al., 2004; González-Sampériz et al., 2005) and alluvial (Gutiérrez and Peña, 1998; Peña et al., 2000, 2004; Andres et al., 2002; Sancho et al., 2008a) records. Nevertheless, the available data are still insufficient to construct a consistent paleoclimatic interpretation.

Saline wetlands on gypsiferous bedrock from Los Monegros (Central Ebro Basin) are in a geological and geomorphological setting that favours the record of a well preserved Late Pleistocene and Holocene lacustrine-fluvial-alluvial slope sedimentary sequence (Sancho et al., 2007). According to the current knowledge of hydrological and geomorphic processes that occur in saline wetlands (Sánchez et al, 2001), playa-lakes (Samper-Calvete and García-Vera, 1998; 
Castañeda and García-Vera, 2008) and gypsiferous slopes (Desir et al., 1995), the Valsalada saline wetland dynamics during the Late Pleistocene and Holocene were controlled by changes in groundwater discharges feeding the endorheic depressions along with changes in runoff and sediment yield supplied from the gypsiferous slopes. Consequently, the morphosedimentary response of this system to climate oscillations shows some differences from the response observed in playa lakes (Stevenson et al., 1991; Davis, 1994; Valero-Garcés et al., 2000a, 2000b, 2004; González-Sampériz et al., 2008) and normal alluvial systems (Peña et al., 2004; Sancho et al., 2008a) in the Central Ebro Basin.

This study aims to provide new data on prevailing environmental conditions during the Late Pleistocene and Holocene times at a regional scale. The palaeoenvironmental interpretation is based on geomorphological, sedimentological, palynological and chronological analyses from morphosedimentary records in saline wetland areas near Zaragoza (Central Ebro Basin).

\section{Study area}

The study area is located near the Leciñena village (Zaragoza province) in the western sector of the Los Monegros district (Central Ebro Basin) (Figure 1). The elevation ranges between $460 \mathrm{~m}$ and $350 \mathrm{~m}$, and the climate is semiarid with strong seasonal contrasts and a high water deficit during summer. The mean annual temperature is $14.5{ }^{\circ} \mathrm{C}$, and the mean annual precipitation is $400 \mathrm{~mm}$. Saline wetlands (the Valsalada system) consist of two depressions (Siscal and Valsalada) drained by the Arroyo Salado (Figures 1 and 2).

The bedrock lithology of this sector of the Tertiary Ebro Basin is composed mainly of nodular and massive gypsum including clays, marls and sandstones (Zaragoza Formation). These materials were deposited in extensive and shallow lacustrine systems with evaporitic environments corresponding to the Miocene tectosedimentary unit UTS5 (Muñoz et al., 2002). Geomorphologically, the Valsalada saline wetland system is located in the western piedmont of the Alcubierre Range, which is the highest central limestones platform in the Ebro basin. This piedmont connected the Alcubierre Platform with the the Gállego River, an important Pyrenean tributary of the Ebro River, with the development of several alluvial-slope stepped levels during the Quaternary (Benito, 1989; Gutiérrez and Peña, 1994; Benito et al., 2000) (Figure 1). Subsequent downcutting of the drainage network favoured the development of wide karstic depressions with saline wetlands controlled by local groundwater discharges and the occurrence of flat-bottomed alluvial-infill valleys (Figure 3a). These geomorphic features are common on Oligocene-Miocene gypsum formations outcropping in the Central Ebro Basin (Gutiérrez and Gutiérrez, 1998).

The Valsalada saline wetlands (Figure 2) are fed by regional groundwater flows from Tertiary bedrock. The low permeability of the bedrock favours a slow flux of water with a long residence time (Sánchez et al., 2001). Consequently, the supplied water shows a high dissolved content, with conductivity values reaching up to $50 \mathrm{dS} / \mathrm{m}$ and $\mathrm{pH}$ values of 8.7 . The mean chemical composition of the groundwater is dominated by chlorides $(8,500 \mathrm{mg} / \mathrm{L})$, sulphides $(6,900 \mathrm{mg} / \mathrm{L})$ and sodium $(10,300 \mathrm{mg} / \mathrm{L})$. Currently, vegetation cover in these saline wetlands is dominated by Phragmites communis, Suaeda vera, Salicornia ramossissima and Tamarix canariensis (BraunBlanquet and de Bolòs, 1957; Peinado-Lorca and Rivas-Martínez, 1987). The surrounding area is dominated by a steppe vegetation (covering less than $50 \%$ of the area in regional terms), leaving small patches of isolated Pinus halepensis, Quercus coccifera, Juniperus thurifera, Rhamnus lycioides, Rosmarinus officinalis, Ephedra fragilis, Pistacia lentiscus, Phillyrea angustifolia, and dry agriculture land use. As in the nearby Alcubierre Range, mesophytes in the region are restricted to particularly humid canyons (Blanco et al., 1997). 


\section{Material and methods}

Geomorphological mapping, based on 1:18,000 scale aerial photographs and 1:5,000 scale orthophotos, allowed differentiation of several stepped morphogenetic surfaces. Mapped morphosedimentary units were extensively field checked, and geomorphic and stratigraphic relations were established. Stratigraphic and sedimentological descriptions as well as sampling for mineralogy, pollen content, and radiocarbon analysis were made in selected outcrops exposed in gully scarps.

The salt composition within the sediments was determined from mineralogical analysis of saline efflorescences using powder X-ray diffraction (Phillips PW 1729 diffractometer). Pollen analysis followed the standard procedure described by Moore et al. (1991) and Dupré (1992). A chemical treatment of $\mathrm{HF}, \mathrm{HCl}$ and $\mathrm{KOH}$ and mineral separation in heavy liquid (Thoulet: density 2.0) was used. Lycopodium clavatum tablets were added to calculate the pollen concentration (Stockmarr, 1971) and to test for the possible sterility of the sediment. A minimum of 250 pollen grains per sample was established as a representative result. Thus, a smaller number of pollen grains is considered to be a sterile sample, and therefore, only the presence of the different taxa is mentioned. Results are plotted and expressed in relative percentages, excluding spores and hydro-hygrophytes from the pollen sum. The diagrams were constructed using the Psimpoll (Bennet, 2002) and Corel Draw programmes. Radiocarbon dating was performed on charcoal samples by the Radiocarbon Laboratory of the Department of Geography at the University of Zurich. The accelerator mass spectrometer (AMS) used in this study is the tandem accelerator at the Institute of Particle Physics at the Swiss Federal Institute of Technology Zurich (ETH). Radiocarbon dates were calibrated using the CalPal software, which uses the most up-to-date data set, the INTCAL04curve (Reimer et al., 2004). The CALPAL2001 curve was also used for the two oldest dates (Lacustrine Unit), as they were outside the limits of the previous calibration curve (dates before 22,000 yr). The CalPal software combines the different available approaches to calibrate ${ }^{14} \mathrm{C}$ ages, such as speleothems, corals or varved sediments data (http://www.calpal.de) (Table 1).

\section{Results}

Based on field studies, three morphosedimentary units that are related to different depositional environments can be clearly identified in the Quaternary record of the Valsalada saline wetlands system (Figure 2). Morphostratigraphic relationships between them (Figure 3) allow the establishment of a sedimentary sequence made up of a lacustrine stage (the oldest), a fluvial phase (the intermediate) and an alluvial slope period (the youngest).

\subsection{Lacustrine unit}

The lacustrine sedimentary unit has mainly been recognised in small outcrops exposed by incision of the Arroyo Salado (Figure 3b). Only the upper portion (1 m thick) of this unit was exposed (Figure 4 and 5a). It consists of an alternation of massive ochre and gray mudstones as well as marls, which are arranged in centimetre-thick tabular beds with some plant remains and lenticular gypsum crystals. These sediments indicate a lacustrine environment. The unit ends with a $7 \mathrm{~cm}$ thick peaty tabular level, which may represent the final filling up of the lake (Figure $5 b)$.

A sample (BSB1) from the upper peat level of this lacustrine unit was taken for pollen analysis and resulted in 361 pollen and spore grains of 29 different taxa, which is considered statistically significant (Figures 4 and 5b). The pollen spectrum contains high amounts of aquatic (Ranunculaceae, Ruppia, Potamogeton, Myriophyllum) and hygrophitic taxa (Cyperaceae, 
Typha) and ferns taxa (Pteridophyta trilete and monolete, Asplenium, Botrychium) with wide variability (Figure 6). The presence of this ensemble reinforces the sedimentary interpretation and indicates a steady palustrine and lacustrine environment with a brackish character. The BSB1 sample indicates that the general vegetation landscape was dominated by herbs (mainly Poaceae) and shrubs (Fabaceae, Lamiaceae, Rhamnus, Rosaceae), with a limited arboreal component including pines (40\%), isolated Juniperus along with a regional presence of deciduous trees (Corylus, Alnus, Salix).

Two radiocarbon dates were obtained from the peat level of this unit (Figure $5 b$ ), providing ages

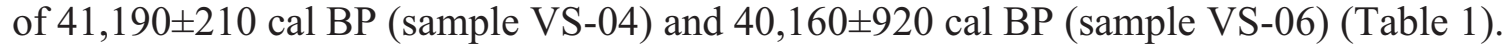

\subsection{Fluvial unit}

The fluvial sedimentary unit outcrops extensively along the bank scarps of the Arroyo Salado (Figure 3a) and in small outcrops corresponding to a lacustrine terrace in the Siscal depression. This unit reaches a maximum thickness of $4 \mathrm{~m}$ (Figure 4) and overlies the earlier lacustrine unit on an erosive contact (Figure 3b). The lower and the upper portion of the fluvial unit consist of grey gravels and grey and ochre sands with lenticular geometries (Figure 4). The gravels present cross bedding, imbricated clasts and internal erosional surfaces (Figure 5c). Current ripples are common in the sandy beds. These sedimentological facies are interpreted as small channel infill with an erosive base and bars deposited by a braided system. The middle part of the unit is dominated by massive brown and grey muds that are usually arranged in centimetre to decimetre tabular beds with abundant vertical root bioturbation, parallel lamination and mud cracks (Figure 5d). They intercalate ochre sands organised in centimetre tabular levels with abundant current ripples. This mud-sand set can be interpreted as an alluvial plain crossed by small fluvial channels.

White salt efflorescences often occur on the surface of the outcrops of this unit Figure 3a), mainly due to water evaporation and crystallisation of soluble salts extracts from the sediments during the spring (Figure 5d). Subsequent runoff can flush these salt crystals down the slope to the valley bottom. Halite $(\mathrm{NaCl})$, thenardite $\left(\mathrm{Na}_{2} \mathrm{SO}_{4}\right)$, and bloedite $\left(\mathrm{Na}_{2} \mathrm{Mg}\left(\mathrm{SO}_{4}\right)_{2} \cdot 4 \mathrm{H}_{2} \mathrm{O}\right)$ are the main mineral phases detected in this unit, though minor amounts of epsomite $\left(\mathrm{MgSO}_{4} \cdot 7 \mathrm{H}_{2} \mathrm{O}\right)$ and hexahydrite $\left(\mathrm{MgSO}_{4} \cdot 6 \mathrm{H}_{2} \mathrm{O}\right)$ are seen. The occurrence of these salts inside the fluvial deposits indicates that the hydrochemical features of the runoff that fed the alluvial system were similar to the present groundwater discharge.

Radiocarbon dated charcoal samples are associated with fires (Figure 5e) that affect the vegetation cover of the alluvial plain. These fires also burned the deposits just below the charcoal level, which is indicated by the occurrence of red colouring in the fine sediments. Samples taken at different sites of this unit have provided calibrated ages with 2 sigma uncertainties of $12,550 \pm 150,6290 \pm 70$ and $3460 \pm 60 \mathrm{cal}$ BP, in the Arroyo Salado alluvial infill, and $14,360 \pm 220$ cal BP in the Siscal lacustrine terrace (Table 1).

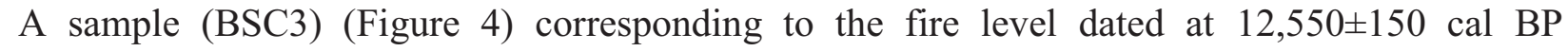
(Younger Dryas event) was taken to determine pollen content. The number of pollen and spore grains was not large enough to be statistically significant and, consequently, only qualitative information rather than proportions can be derived from the identified taxa (Figure 6). The poor preservation of palynomorphs could be related to oxidation processes associated with frequent air exposure of the Valsalada fluvial records due to the arid conditions. Conifers (Pinus and Juniperus) are the only noticeable arboreal component. Neither deciduous trees nor aquatic taxa associated with moisture-rich conditions have been observed, in contrast to the BSB1 pollen sample from the lacustrine unit. Nevertheless, steppe herbaceous taxa such as Artemisia, 
Chenopodiaceae or the heliophyte Helianthemum, have been identified. In addition, this sample contains many microcharcoal remnants as well as Asphodelus, which indicate the occurrence of fire events affecting vegetation cover from the saline wetlands system.

\subsection{Alluvial slope unit}

184

185

186

187

188

189

190

A morphosedimentary, alluvial slope unit occurs as a coalescing, small alluvial fan system entering the bottom valley of the Arroyo Salado from the surrounded boundary gypsiferous relief (Figure 3a). This unit covers the preceding fluvial unit, that was clearly incised during a previous erosion stage (Figure 3c), and develops a well-preserved, gentle slope, morphogenetic surface. This unit represents the final sedimentary stage in the evolution of the Valsalada system, prior to an intensive period of entrenchment lasting to the present. The resulting scarps show excellent exposures of this unit that are clearly identified by the silty-sandy gypsiferous nature of the deposits (Figure 5f).

Outcrops of the alluvial unit exceed $3 \mathrm{~m}$ in thickness (Figure 4). The unit is constituted by a heterolytic set of silts-sands, breccias and ochre sandstones that are poorly cemented by gypsum. These facies are arranged in irregular beds with lenticular geometries and they present vertical bioturbation and dispersed gypsum clasts (Figure $5 \mathrm{~g}$ ). The gypsiferous nature of the sediments points to the closest relief as the only source area resulting in a short transport. Geomorphologic and sedimentary features indicate that this unit could correspond to small lateral alluvial fans.

Inside the alluvial slope unit, a small fireplace has been identified (Figure 5f). Charcoal remnants have provided a calibrated age of $1540 \pm 80 \mathrm{cal}$ BP ( 410 AD; sample VS-02) (Table 1; Figure 4 ), indicating that this unit was synchronous with the Late Roman period (V century).

\section{Discussion}

According to the geomorphic, sedimentary, palynological and chronological data, three morphosedimentary units (lacustrine, fluvial and alluvial slope) can be differentiated in the Valsalada saline wetlands system. Data presented here complement and reinforce the available paleoenvironmental scenery for the Central Ebro Basin during the Late Pleistocene and Holocene.

\subsection{The Late Pleistocene lacustrine stage}

Very low salinity lacustrine environments occupying karstic depressions on gypsum bedrock occur in the Central Ebro Basin during the Late Pleistocene (about $40 \mathrm{ka}$ ). The occurrence of these lacustrine systems is indicative of a period of increased water availability (runoff and/or groundwater discharges) at regional scale. Pollen assemblages show prevailing aquatic taxa (Ranunculaceae, Ruppia, Potamogeton, Myriophyllum) and hygrophytes (Cyperaceae, Typha), which indicates permanent palustrine and lacustrine environments with brackish water. The occurrence of Potamogeton and Myriophyllum provide support for a period of positive hydrological balance. In addition, Cyperaceae and Typha colonised a marginal belt of the lake. Seasonal hydrological fluctuations in the lake could probably be significant.

In this unit, the dominant arboreal pollen is Pinus nigra-sylvestris type (40\%), which is currently located at higher altitudes, indicating that temperatures would be cool or even cold. In addition, the pollen record includes grasses (Poaceae), other herbs (Liliaceae, Urticaceae, Carduae and Asteroideae), shrubs (Fabaceae, Lamiaceae, Rhamnus, Rosaceae) and isolated junipers, indicating a very open landscape. The presence of Corylus, Alnus and Salix demonstrates the existence of riparian formations and refugial areas in the region (González-Sampériz et al., 2004, 
2005). Although the dominant arboreal pollen (Pinus nigra-sylvestris and Juniperus sp.) is normally associated with generally dry conditions, no typical steppe taxa such as Artemisia, Cichorioideae, Chenopodiaceae or Rumex, have been identified. In contrast, the large proportions of ferns and hydro-hygrophytes indicate local moisture-rich conditions.

Although numerical ages from Late Pleistocene records in the Ebro Basin are still scarce, it is possible to establish a close correlation between the lacustrine record $(41.2 \pm 0.2$ and $40.2 \pm 0.9 \mathrm{ka}$ cal BP) from Valsalada and other regional morphoestratigraphic sequences. Sancho et al. (2004) and Lewis et al. (2009) reported a phase of glacier advance, evidenced by a terminal moraine at Senegüé (Gállego River valley, Central Pyrennes), at $36 \pm 3$ ka using optically stimulated luminiscence (OSL). The top of the lacustrine unit from Valsalada is slightly chronologically delayed with relation to the terrace levels identified in the Gállego River (45 $\pm 3 \mathrm{ka})$ and the Cinca River ( $47 \pm 4 \mathrm{ka})$ valleys (Northern Ebro Basin). Both valleys were also dated by OSL (Sancho et al., 2004; Lewis et al., 2009). Correlation between glacial phases and terraces indicates a strong increase in water discharge and in sediment availability related to the transition to deglaciation. The same conditions can be observed in areas nearby to Valsalada, for instance the San Juan de Mozarrifar record (Valero-Garcés et al., 2004; González-Sampériz et al., 2005). This area underwent strong episodes of deglaciation water discharges in a general open landscape dominated by pines, while mesothermophytes occurred in regional refugial areas.

Fuller et al. (1998) and Macklin et al. (2002) reported a large-scale valley floor aggradation period between 39 and $36 \mathrm{ka}$ in the Guadalope River valley (Southern Ebro Basin). This coincided with stadial or neoglacial events characterised by a steppe vegetation cover and an increase in winter storm frequency. Finally, Gutiérrez et al. (2006) provided a radiocarbon age of $35,570 \pm 490$ for a triangular slope facet development stage in the Central Ebro Basin, indicating that accumulation periods on the slopes correspond to cold environmental conditions.

Using the lacustrine unit in Valsalada it is possible to infer an environmental context for the Central Ebro Basin for this time period. The environment was characterised by a cool-cold climate with relatively wet conditions in the area. The moisture availability could be associated with an increase in precipitation and/or a decrease in evaporation. The paleoclimatic conditions, included in the MIS 3 period (around 49-26 ka BP), should be evaluated with caution because the chronological uncertainties associated with this period and the well-known complexity of this interstadial (i.e., see the Area Longa sequence, in NW Spain, by Gómez-Orellana et al., 2007). However, in general terms, conditions similar to those seen in the Central Ebro Basin are well constrained in other palaeoclimatic Iberian sequences (with cold but more arid conditions around 40 ka BP), such as Fuentillejo maar-lacustrine record in Central Spain (Vegas et al., 2010) or Boquete de Zafarraya (Lebreton et al., 2003) and the Carihuela (Carrión, 1992; Fernández et al., 2007) caves in Southern Iberia, among others. Marine records indicate similar conditions with cold deep-water temperatures occurring during the Heinrich Event 4 (39-40 ka BP) in the NorthAtlantic, just in front of southwest Europe (Sánchez-Goñi et al., 2000) and in the western Mediterranean Sea (Fletcher and Sánchez-Goñi, 2008; Cacho et al., 2006; Frigola et al., 2008).

\subsection{The Late-glacial and Early-Mid Holocene fluvial phase}

The next morphosedimentary stage took place approximately between 14.4 and $3.5 \mathrm{ka}$ cal BP and represents the replacement of lacustrine environments by fluvial systems. It is possible to differentiate two sections in the new fluvial sequence. The bottom of the sequence is older than the ages indicated for the lacustrine sequence and is composed of gravels linked to fluvial channels. This suggests a highly active phase of morphodynamic processes that was climatically controlled. Similar sedimentary activity signals, associated with climate fluctuations have been recognised in infilled valleys near Zaragoza city (Andres et al., 2002) from 17,765-15,440 
(Mystery Interval) to 13,140-12,650 cal BP (Intra Allerod Cold Period or IACP-beginning of the Younger Dryas), and in Bardenas Reales of Navarra from 20.6 \pm 0.9 (Last Glacial Maximum) to Fuller et al. (1998) reported a fluvial aggradational phase in the Guadalope River valley at 19-16 ka (Mystery Interval) and Lewis et al. (2009) identified a terrace of the Cinca River at $11 \pm 1 \mathrm{ka}$ (Younger Dryas). Evidence of alluvial deposition by fluvial channels in Valsalada is clearly indicative of increasing water discharge and sediment availability during some episodes of the Late-glacial period. This stage could have occurred at regional scale and is probably related to cold conditions.

Most of the fluvial sequence is composed of fine sediments deposited in floodplain environments. Sands and muds are characterised by common bioturbation features, evidence of fire and salt cements. Pollen amounts in the sample correspond to the $12,550 \pm 150$ cal BP moment (BSB3) were not statistically significant. Nevertheless, the observed pollen record points to drier environmental conditions than the previous lacustrine unit required because neither deciduous trees nor aquatic plants have been observed. In addition, there is clear evidence of the presence of conifers (Pinus and Juniperus) as the only arboreal component in the landscape alongside steppe herbs like Artemisia or Chenopodiaceae, which were not recorded in the previous lacustrine unit. This pollen ensemble clearly implies cold and arid conditions, which could likely be correlated with the Younger Dryas period that is widely recognised in many terrestrial records throughout the Iberian Peninsula (Montserrat, 1992; Jalut et al., 1992; PérezObiol and Julià, 1994; Allen et al., 1996; Peñalba et al., 1997; Carrión, 2002; Vegas et al., 2003; Morellón et al., 2008, 2009; Moreno et al., 2009; between many others).

In addition, the abundance of microcharcoal remnants indicate that fires occurred. This is confirmed by the presence of Asphodelus, a plant usually associated with fire events (Jalut, 1991; García-Ruiz et al., 2001; González-Sampériz, 2004). The red colouring of fine sediments just below the fire level further supports this. Commonly occurring wildfires in the Central Ebro Basin during the Early Holocene has been proposed by Davis and Stevenson (2007), suggesting that a change in seasonal aridity is the main factor controlling these fire events. Linstädter and Zielhofer (2010) indicate that local fire recurrences in other Western Mediterranean areas are the consequence of short-term changes in humidity during the Middle and Late Holocene periods.

Salt crystallisation in the porous system of fluvial sediments indicates that hydrochemical characteristics of the runoff were similar to the present-day characteristics. The Valsalada system was likely fed by saline groundwater inputs rather than by runoff derived from the drainage area. This may be interpreted in terms of low rainfall rates and a negative water balance under arid conditions. In this hydrodynamic context, alluvial activity is characterised by very low sedimentation rates, resulting in condensed but continuous stratigraphic sequences, as evidenced by supplied chronological data (Table 1). In fact, marked erosional features have not been recognised. Despite a sparce vegetation cover under arid conditions, sediment supply from gypsiferous hillslopes should be low, as it has been observed today in experimental plots of the semiarid Ebro Basin (Desir et al., 1995).

In general terms, Holocene alluvial sedimentary dynamics in semiarid regions is activated under enhanced arid conditions favouring high rates of alluviation (Waters and Haynes, 2001; Faust et al., 2004; Peña et al., 2004; Sancho et al., 2008a). Undoubtedly, the differential response of the Valsalada alluvial system, characterised by low sedimentation rates, was controlled by the small size of the endorheic catchment, the low slope gradients and the feeding of the system by a slow groundwater flux with high salinity. 
It is clear that pollen, salts, fires and sedimentary features indicate prevailing dry climate conditions during the Younger Dryas (pollen data) and during different episodes of the Early and Middle Holocene in the Valsalada area. Hovewer, the stratigraphic sequence also indicates that this alluvial system is not sensitive enough to record and preserve the millennial- to centennialscale climatic variability during the Late Pleistocene and Holocene in northeast Iberia that is usually provided by regional lacustrine (Pérez-Obiol and Julià, 1994; Valero-Garcés et al., 2000a, 2000b, 2004, 2008; Morellón et al., 2008, 2009), fluvial (Rico et al., 2001; Thorndycraft and Benito, 2006; Benito et al., 2008), alluvial (Peña et al., 2004; Sancho et al., 2008a) or pollen archives (Jalut et al., 1992; Montserrant, 1992; Stevenson, 2000; González-Sampériz et al., 2005, 2006, 2008), as well as Mediterranen marine records (Cacho et al., 2006; Frigola et al., 2008; Melki et al., 2009) and global sources (Mayewski et al., 2004).

Palaeoenvironmental information available for northeast Spain clearly shows cold and arid conditions related to the YD, a more positive water balance in the lakes and an increase in forest formations during the Early Holocene, and more arid conditions for the Middle Holocene. These do have some fluctuations, though the fluvial Valsalada record does not provide complete and continuous palaeoclimatic information for the Late glacial and Early-Mid Holocene periods.

\section{3 The Late Holocene alluvial slope period}

The Late Holocene alluvial slope unit $(1540 \pm 80$ cal BP) represents a period of high alluvial activity and is reported in different sectors of the Central Ebro Basin (Peña et al., 2000, 2004; Sancho et al., 2008a). This regional stage of accumulation is Late Roman in age, and is controlled by denudation of surrounding slopes mantled with gypsiferous silts that were activated under dry and warm conditions typical of the Subatlantic period. This is a fragile semiarid environment and the high density of Roman settlements around Zaragoza city (former Caesaraugusta), as well as in the rest of the Central Ebro Basin, and the resulting human action (mainly overgrazing, agriculture and deforestation) could trigger and enhance the intensity of erosive processes in a very open vegetation landscape (González-Sampériz and Sopena, 2002; González-Sampériz, 2004; Peña et al., 2004; Sancho et al., 2008a). Human influence on alluvial system dynamics has also been reported in other semiarid areas (Gonzalez, 2001; Faust et al., 2004; Zeilhofer and Faust, 2008; Zielhofer et al., 2008).

\section{Conclusions}

The Valsalada saline wetlands area contains an exclusive depositional sequence composed of three sedimentary units depositing during the Late Pleistocene and Holocene. The Valsalada record shows the first well-dated paleoclimatic information using pollen results for $40 \mathrm{ka} \mathrm{BP}$ and the Younger Dryas event in the lowlands of the central Ebro Basin. Several palaeoenvironmental stages can be inferred from this detailed study and are supported by radiocarbon dating as well as by including geomorphological mapping, stratigraphic and sedimentological descriptions, pollen studies and mineralogical analysis:

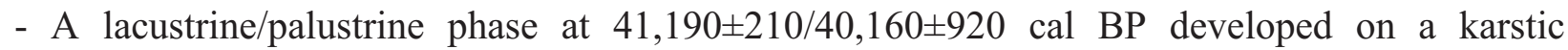
depression on gypsiferous bedrock. The pollen record indicates wet and cool-cold climate conditions that reinforce the paleoclimatic regional scenery at this time, characterised by deglacial melwater pulses and high moisture availability.

- A fluvial period related to the Late glacial period, accompanied by the deposition of gravels, has been identified previous to the general fluvial stage that deposited the fine sediment sequences (from $14,360 \pm 220$ to $3460 \pm 60 \mathrm{cal} \mathrm{BP}$ ). This last phase, spanning from YD/Holocene transition to Middle/Late Holocene, is characterised (with some fluctuations) by episodic cold 
periods and a general trend toward well established arid conditions during the Middle Holocene. Conifers and steppe pollen assemblages during the Younger Dryas, periodic wild fire remnants and ubiquitous salt masses within the sediments are evidence of arid conditions. This alluvial system is characterised by low sedimentation rates, giving rise to slow rate sedimentationsequences fed by saline groundwater discharges in the karstic depressions of Valsalada. The response of the Valsalada alluvial system is quite different from the observed response at a regional scale and shows a low sensitivity to short-term (centennial-millennial) climatic changes. Nevertheless it provides interesting punctual data to complete the available regional paleoenvironmental information. The main factors driving the fluvial activity in the Valsalada saline wetlands are proposed to include the geomorphic configuration of the system, which is characterised by karstified gypsiferous bedrock, the small size of the catchment, and a low but continuous saline groundwater discharge.

- Along the Arroyo Salado, an important alluvial slope stage has been recognised during Late

374

375

376

377

Roman Period $(1540 \pm 80$ cal BP). This is a well-documented regional sedimentary phase characterised by a thick gypsiferous silty sequence under dry and warm conditions. In this fragile scenery, human action could increase the intensity of erosive processes on slopes and the subsequent accumulation in the valleys.

The palaeoenvironmental information derived from a three stage lacustrine, fluvial and alluvial infill in Valsalada (Central Ebro Basin) substantially improves the incomplete regional palaeoclimatic record for northeast Spain during the Late Pleistocene and Holocene.

\section{Acknowledgements}

This work was supported by projects CGL2006-08973/BTE, CGL2009-10455/BTE, CGL200907992 and CSD2007-00067 of the Spanish Government and the European Regional Development Fund. This is a contribution by PaleoQ, GCC and Cuencas Sedimentarias Continentales groups (Aragón Regional Government). We are grateful to the anonymous reviewers for their helpful comments.

\section{References}

Allen, J.R.M., Huntley, B., Watts, W.A., 1996. The vegetation and climate of northwest Iberia over the last 14,000 yr. Journal Quaternary Science 11, 125-147.

Andres, A., Ries, J., Seeger, M., 2002. Pre-Holocene sediments in the Barranco de las Lenas, Central Ebro Basin, Spain, as indicators for climate-induced fluvial activities. Quaternary International 93-94, 65-72.

Benito, G., 1989. Geomorfología de la Cuenca Baja del río Gállego. PhD dissertation, Universidad de Zaragoza.

Benito, G., Gutiérrez, F., Pérez-González, A., Machado, M.J., 2000. Geomorphological and sedimentological features in Quaternary fluvial systems affected by solutioninduced subsidence (Ebro Basin, Spain). Geomorphology 33, 209-224.

Benito, G., Thorndycraft, V.R., Rico, M., Sánchez-Moya, Y., Sopeña, A., 2008. Palaeoflood and floodplain records from Spain: Evidence for long-term climate variability and environmental changes. Geomorphology 101, 68-77. 
Bennet, K., 2002. Documentation for Psimpoll 4.10 and Pscomb 1.03. C programs for plotting pollen diagrams and analysing pollen data. University of Cambridge. Cambridge.

Blanco, E., Casado, M., Costa, M., Escribano, R., García Antón, M., Génova, M., Gómez, A., Moreno, J., Morla, C., Regato, P., Sainz Ollero, H., 1997. Los bosques ibéricos. Una interpretación geobotánica. Planeta, Barcelona.

Braun-Blanquet, J., de Bolòs, O., 1957. Les groupements végétaux du bassin moyen de l'Ebre et leur dynamisme. Annales Estación Experimental de Aula Dei V, Zaragoza.

Cacho, I., Shackleton, N., Elderfield, H., Sierro, F.J., Grimalt, J.O., 2006. Glacial rapid variability in deep-water temperature and 180 from the Western Mediterranean Sea. Quaternary Science Reviews 25, 3294-3311.

Carrión, J.S., 1992. Late quaternary pollen sequence from Carihuela Cave, Southern Spain. Review of Palaeobotany and Palynology 71, 37-77.

Carrión, J.S., 2002. Patterns and processes of Late Quaternary environmental change in montane region of southwestern Europe. Quaternary Science Reviews 21, 2047-2066.

Castañeda, C., García Vera, M.A., 2008. Water balance in the playa-lakes of an arid environment. Monegros, NE Spain. Hydrogeology Journal 16, 87-102.

Davis, B., 1994. Palaeolimnology and Holocene environmental change from endorheic lakes in the Ebro Basin, north-east Spain, Ph. D. Thesis, University of Newcastle upon Tyne.

Davis, B., Stevenson, A., 2007. The 8.2 ka event and Early-Mid Holocene forests, fires and flooding in the Central Ebro Desert, NE Spain. Quaternary Science Reviews 26, 1695-1712.

Desir, G., Sirvent, J., Gutiérrez, M., Sancho, C., 1995. Sediment Yield from Gypsiferous Degraded Areas in the Middle Ebro Basin (NE, Spain). Physics and Chemistry of the Earth 20, 385-393.

Dupré, M., 1992. Palinología. Cuadernos Técnicos de la Sociedad Española de Geomorfología, $5,1-30$.

Faust, D., Zielhofer, Ch., Baena, R., Díaz del Olmo, F., 2004. High-resolution fluvial record of late Holocene geomorphic change in northern Tunisia: climatic or human impact?. Quaternary Science Reviews 23, 1757-1775.

Fernández, S., Fuentes, N., Carrión, J.S., González-Sampériz, P., Montoya, E., Gil, G., VegaToscano, G., Riquelme, J.A., 2007. The Holocene and Late Pleistocene pollen sequence of Carihuela Cave, southern Spain. Geobios 40, 75-90.

Fletcher, W.J., Sánchez-Goñi, M.F., 2008. Orbital- and sub-orbital-scale climate impacts on vegetation of the western Mediterranean basin over the last 48,000 yr. Quaternary Research 70, 451-464.

Frigola, J., Moreno, A., Cacho, I., Canals, M., Sierro, F.J., Flores, J.A., Grimalt, J.O., 2008. Evidence of abrupt changes in Western Mediterranean Deep Water circulation during the last 50 kyr: a high-resolution marine record from the Balearic Sea. Quaternary International 181, 88104. 
Fuller, I.C., Macklin, M.G., Lewin, J., Passmore, D.G., Wintle, A.G., 1998. River response to 440 high-frequency climate oscillations in southern Europe over the past $200 \mathrm{ky}$. Geology 26, 275441278.

442 García-Ruiz, J.M., Valero-Garcés, B., González-Sampériz, P., Lorente, A., Martí Bono, C., 443 Beguería, S., Edwards, L., 2001. Stratified screes in the central Spanish Pyrenees: paleoclimatic 444 implications. Permafrost and Periglacial Processes 12, 233-242.

445 Gómez-Orellana, L., Ramil-Rego, P., Muñoz-Sobrino, C., 2007. The Würm in NW Iberia, a 446 pollen record fron Area Longa (Galicia). Quaternary Research 67, 438-452.

447 Gonzalez, M.A., 2001. Recent formation of arroyos in the Little Missouri Badlands of southwestern North Dakota. Geomorphology 38, 63-84.

449 González-Sampériz, P., 2004. Evolución paleoambiental del sector central de la cuenca del Ebro durante el Pleistoceno superior y Holoceno. Instituto Pirenaico de Ecología-CSIC. Zaragoza.

451 González-Sampériz, P., Sopena, M.C., 2002. Recent Holocene palaeoenvironmental evolution in the Central Ebro Basin (NE Spain). Quaternary International 93-94, 177-190.

453 González-Sampériz, P., Valero-Garcés, B., Carrión García, J.S., 2004. Was the Ebro valley a refugium for temperate trees? Anales de Biología 26, 13-20.

González-Sampériz, P., Valero-Garcés, B.L., Carrión, J.S., Peña-Monné, J.L., García-Ruiz, J.M., Martí-Bono, C., 2005. Glacial and Lateglacial vegetation in northeastern Spain: New data and a review. Quaternary International 140/141, 4-20.

González-Sampériz, P., Valero-Garcés, B., Moreno, A., Morellón, M., Navas, A., Machín, J., Delgado-Huertas, A., 2008. Vegetation changes and hydrological fluctuations in the Central 460 Ebro Basin (NE Spain) since the Late Glacial period: Saline lake records. Palaeogeography, 461 Palaeoclimatology, Palaeoecology 259, 157-181.

González-Sampériz, P., Valero-Garcés, B., Moreno, A., Jalut, G., García-Ruiz, J.M., MartíBono, C., Delgado-Huertas, A., Navas, A., Otto, T., Dedoubat, J.J., 2006. Climate variability in the Spanish Pyrennes during the ast 30,000 yr revealed by the El Portalet sequence. Quaternary Research 66, 38-52.

466 González-Sampériz, P., Valero-Garcés, B., Moreno, A., Morellón, M., Navas, A., Machín, J., 467 Delgado-Huertas, A., 2008. Vegetation changes and hydrological fluctuations in the Central 468 Ebro Basin (NE Spain) since the Late Glacial period: Saline lake records. Palaeogeography, 469 Palaeoclimatology, Palaeoecology 259, 157-181.

470 Gutiérrez, M., Gutiérrez, F., 1998. Geomorphology of the Tertiary gypsum formations in the 471 Ebro Depression (Spain). Geoderma 87, 1-29.

472 Gutiérrez, M., Peña, J.L., 1994. Depresión del Ebro, in: Gutiérrez, M. (Ed.), Geomorflogía de 473 España, Rueda, Madrid, pp. 305-349.

474 Gutiérrez, M., Gutiérrez, F., Desir, G., 2006. Considerations on the chronological and causal 475 relationships between talus flatirons and palaeoclimatic changes in central and northeastern 476 Spain. Geomorphology 73, 50-63. 
Gutiérrez, M.; Sancho, C., Arauzo, T., Peña, J.L., 1998. Evolution and paleoclimatic meaning of the talus flatirons in the Ebro Basin, northeast Spain, in: Alsharhan, A., Glennie, K., Whittle, G., Kendall, C. (Eds.), Quaternary Deserts and Climatic Change. Balkema. Rottterdam, pp. 593-599.

Jalut, G., 1991. Le pollen, traducteur du paysage agraire. Pour une archéologie agraire, 345-368.

Jalut, G., Montserrat, J., Fontugne, M., Delibrias, G., Vilaplana, J., Juliá, R., 1992. Glacial to Interglacial vegetation changes in the northern and southern Pyrenees: Deglaciation, vegetation cover and chronology. Quaternary Science reviews 11, 449-480.

Lebreton, V., Renault-Miskovsky, J., Carrión, J.S., Dupré, M., 2003. Etude palynologique du remplissage de la grote du Boquete de Zafarraya, in: Barroso, C., de Limley, H. (Eds.), La Grotte Boquete de Zafarraya, Monographie Institut de Pléontologie Humaine, Junta de Andalucia. Consejería de Cultura. Málaga, pp. 629-660.

Lewis, C., McDonald, E., Sancho, C., Peña, J.L., Rhodes, E., 2009. Climatic implications of correlated Upper Pleistocene glacial and fluvial deposits on the Cinca and Gállego Rivers (NE Spain) based on OSL dating and soil stratigraphy. Global and Planetary Change 67, 141-152.

Linstädter, A., Zielhofer, Ch., 2010. Regional fire history shows abrupt responses of Mediterranean ecosystems to centennial-scale climate change (Olea-Pistacia woodlands, NE Morocco). Journal of Arid Environments 74, 101-110.

Macklin, M.G., Fuller, I.C., Lewin, J., Maas, G.S., Passmore, D.G., Rose, J., Woodward, J.C., Black, S., Hamlin, R.H.B., Rowan, J.S., 2002. Correlation of fluvial sequences in the Mediterranean basin over the last $200 \mathrm{ka}$ and their relationship to climate change. Quaternary Science Reviews 21, 1633-1641.

Mayewski, P.A., Rohling, E.E., Stager, J.C., Karlén, W., Maasch, K.A., Meeker, L.D., Meyerson, E.A., Gasse, F., van Kreveld, S., Holmgren, K., Lee-Thorp, J., Rosqvist, G., Rack, F., Staubwasser, M., Schneider, R.R., Steig, E.J., 2004. Holocene climate variability. Quaternary Research 62, 243-255.

Melki, T., Kallel, N., Jorissen, F.J., Guichard, F., Dennielou, B., Berné, S., Labeyrie, L., Fontugne, M., 2009. Abrupt climate change, sea surface salinity and paleoproductivity in the western Mediterranean Sea (Gulf of Lion) during the last 28 kyr. Paleogeography, Palaeoclimatology, Palaeoecology 279, 96-113.

Montserrat, J., 1992. Evolución glaciar y postglaciar del clima y la vegetación en la vertiente sur del Pirineo: Estudio palinológico. Monografías del Instituto Pirenaico de Ecología 6, Instituto Pirenaico de Ecología, CSIC, Zaragoza.

Moore, P., Webb, J.A., Collinson, A., 1991. An illustrated guide to pollen analysis. Hodder abd Stroughton, London.

Morellón, M., Valero-Garces, B., Moreno, A., Gonzalez-Samperiz, P., Mata, P., Romero, O., Maestro, M., Navas, A., 2008. Holocene palaeohydrology and climate variability in Northeastern Spain: the sedimentary record of Lake Estanya (Pre-Pyrenean range). Quaternary International $181,15-31$.

Morellón, M., Valero-Garcés, B., Vegas-Vilarrúbia, T., González-Sampériz, P., Romero, O., Delgado-Huertas, A., Mata, P., Moreno, A., Rico, M., Corella, J.P., 2009. Lateglacial and 
Holocene palaeohydrology in the western Mediterranean region: the Lake Estanya record (NE 518 Spain). Quaternary Science Reviews 28, 2582-2599.

Moreno, A., Valero-Garcés, B., Jiménez-Sánchez, M., Domínguez, M.J., Mata, P. Navas, A., González-Sampériz, P., Stoll, H., Farias, P., Morellón, M., Corella, J.P., Rico, M., 2009. Glacial evolution and climate variability since last deglaciation in the Picos de Europa National Park (Cantabrian Mountains, Northern Spain). Journal of Quaternary Science, DOI: 10.1002/jqs.1265.

Muñoz, A., Arenas, C., González, A., Luzón, A., Pardo, G., Pérez, A., Villena, J., 2002. Ebro basin (norteastern Spain), in Gibbons, W., Moreno, M.T. (Eds.). The Geology of Spain, Geological Society, London, pp. 301-309.

Peinado-Lorca, M., Rivas-Martínez, S. (Eds.), 1987. La vegetación de España. Colección Aula Abierta. Alcalá de Henares.

Peña, J.L., Echeverría, M.T., Chueca, J., Julián, A., 2000. Processus géomorphologiques d'accumulation et incision pendant 1'Antiquité Classique et ses rapport avec l'activité humaine et les changemenmts climatiques holocènes dans la vallée de la Huerva (Bassin de 1'Ebre, Espagne), in: Vermeulen, F., de Dapper, M. (Eds.). Geoarchaeology of the Landscapes of Classical Antiquity. Peeters, Leuven, pp. 151-159.

Peña, J.L., Julián, A., Chueca, J., Echeverría, M.T., Ángeles, G., 2004. Etapas de evolución holocena en el valle del río Huerva: Geomorfología y Geoarqueología, in: Peña, J.L., Longares, L.A., Sánchez, M., (Eds.). Geografía Física de Aragón: aspectos generales y temáticos. Universidad de Zaragoza-Institución Fernando el Católico, Zaragoza, pp. 289-302

Peñalba, M.C., Maurice, A., Guiot, J., Duplessy, J.C., de Beaulieu, J.L., 1997. Termination of the last glaciation in the Iberian Peninsula Inferred from the Pollen Sequence of Quintanar de la Sierra. Quaternary Research 48, 205-214.

Pérez-Obiol, R., Julià, R., (1994. Climate change on the Iberian Peninsula recorded in a 30,000Yr pollenrecord from Lake Banyoles. Quaternary Research 41, 91-98.

Reimer, P.J., Baillie, M.G.L., Bard, E., Bayliss, A., Beck, J.W., Bertrand, C.J.H., Blackwell, P.G., Buck, C.E., Burr, G.S., Cutler, K.B., Damon, P.E., Edwards, R.L., Fairbanks, R.G., Friedrich, M., Guilderson, T.P., Hogg, A.G., Hughen, K.A., Kromer, B., McCormac, G., Manning, S., Ramsey, C.B., Reimer, R.W., Remmele, S., Southon, J.R., Stuiver, M., Talamo, S., Taylor, F.W., van der Plicht, J., Weyhenmeyer, C.E., 2004. IntCa104. Terrestrial Radiocarbon Age Calibration, 0-26 Cal Kyr B.P. Radiocarbon 46, 1029-1058.

Rico, M., Benito, G., Barnolas, A., 2001. Combined palaeoflood and rainfall-runoff assessment of mountain floods (Spanish Pyrenees). Journal of Hydrology 245, 59-72.

Samper-Calvete, F.J., García-Vera M.A., 1998. Inverse modeling of groundwater flow in the semiarid evaporitic closed basin of Los Monegros, Spain. Hydrogeology Journal 6, 33-49.

Sánchez Navarro, J.A., Coloma López, P., Pérez García, A., 2001. Saline wetlands related to groundwater flows from low permeability Tertiary formations in the Somontano area of Huesca, Spain. Hydrological Processes 15, 633-642. 
Sánchez-Goñi M.F., Turon J.L., Eynaud F., Gendreau S., 2000. European climatic response to millennial-scale changes in the atmosphere-ocean system during the Last Glacial Period. Quaternary Research 54, 394-403.

Sancho, C., Peña, J.L., Lewis, C., McDonald, E., Rhodes, E., 2004. Registros fluviales y glaciares cuaternarios en las cuencas de los ríos Cinca y Gállego (Pirineos y depresión del Ebro), in: Colombo, F., Liesa, C.L., Meléndez, G., Pocoví, A., Sancho, C., Soria, A.R., (Eds.), Itinerarios Geológicos por Aragón. Sociedad Geológica de España, Geo-Guías 1, 181-205.

Sancho, C., Muñoz, A., Peña, J.L., González, P., 2007. Evolución morfosedimentaria del sistema aluvial de Valsalada (Leciñena, Los Monearos) durante el Pleistoceno superior-Holoceno: aproximación paleoambiental. Geogaceta 41, 199-202.

Sancho, C., Muñoz, A., Rhodes, E., McDonald, E., Peña, J.L., Benito, G., Longares, L.A., 2008b. Morfoestratigrafía y cronología de registros fluviales del Pleistoceno superior en Bardenas Reales de Navarra: implicaciones paleoambientales. Geogaceta 45, 47-50.

Sancho, C., Peña, J.L., Muñoz, A., Benito, G., McDonald, E., Rhodes, E.J. and Longares, L.A., 2008a. Holocene alluvial morphosedimentary record and environmental changes in the Bardenas Reales Natural Park (NE Spain). Catena 73, 225-238.

Stevenson, A., 2000. The Holocene forest history of the Montes Universales, Teruel, Spain. The Holocene 10, 603-610.

Stevenson, A., Macklin, M., Benavente, J., Navarro, C., Passmore, D., Davis, B., 1991. Cambios ambientales durante el Holoceno en el Valle del Ebro: sus implicaciones arqueológicas. Cuaternario y Geomorfología 5, 149-164.

Stockmarr, J., 1971. Tablets with spores used in absolute pollen analysis. Pollen et Spores 13, 614-621.

Thorndycraft, V.R., Benito, G., 2006. The Holocene fluvial chronology of Spain: Evidence from a newly compiled radiocarbon database. Quaternary Science Reviews 25, 223-234.

Valero-Garcés, B.L., González-Sampériz, P., Delgado-Huertas, A., Navas, A., Machín, J., Kelts, K., 2000a. Late Glacial paleohydrology and vegetational change in Salada Mediana, Central Ebro Basin, Spain. Quaternary International 73/74, 29-46.

Valero-Garcés, B.L., Navas, A., Machin, J., Stevenson, T., Davis, B., 2000b. Responses of a saline lake ecosystems in semi-arid regions to irrigation and climate variability. The history of Salada Chiprana, Central Ebro Basin, Spain. Ambio 26, 344-350.

Valero-Garcés, B., González-Sampériz, P., Navas, A., Machín, J., Delgado-Huertas, A., PeñaMonné, J.L., Sancho-Marcén, C., Stevenson, T., Davis, B., 2004. Paleohydrological fluctuations and steppe vegetation during the last glacial maximum in the central Ebro valley (NE Spain). Quaternary International 122, 43-55.

Valero-Garcés, B., Moreno, A., Navas, A., Mata, P., Machín, J., Delgado-Huertas, A., GonzálezSampériz, P., Schwalb, A., Morellón, M., Cheng, H., Edwards, R.L., 2008. The Taravilla lake and tufa deposits (Central Iberian Range, Spain) as palaeohydrological and palaeoclimatic indicators. Palaeogeography, Palaeoclimatology, Paleoecology 259, 136-156. 

cal. Ka BP from the Fuentillejo maar-lacustrine record (Campo de Calatrava Volcanic Field, Spain). Journal of Quaternary Science, DOI:10.1002/jqs.1262.

602 Waters, M.R., Haynes, C.V., 2001. Late Quaternary arroyo formation and climate change in the 603 American Southwest. Geology 29, 399-402.

Zeilhofer, Ch., Faust, D., 2008. Mid- and Late Holocene fluvial chronology of Tunisia. Quaternary Science Reviews 27, 580-588.

606

607

608

609

Zielhofer, Ch., Faust, D., Linstädter, J., 2008. Late Pleistocene and Holocne alluvial archives in the Southwestern Mediterranean: Changes in fluvial dynamics and past human response. Quaternary International 181, 39-54.

\section{Figure captions}

Figure 1. Location and geomorphological map of the Valsalada saline wetland system.

Figure 2. Oblique aerial photograph of the Valsalada saline wetlands near Leciñena (Central Ebro Basin).

Figure 3. Field pictures of the Arroyo Salado infilled valley. Geomorphic setting (a) and field relationships between the lacustrine unit overlaid by the fluvial unit (b), and the alluvial slope unit overlaying the fluvial unit (c).

Figure 4. Stratigraphic profiles (see location in figure 1) corresponding to the morphosedimentary units in the Valsalada area. Location of pollen and some radiocarbon samples are indicated in the profiles.

Figure 5. Sedimentary characteristics of the differentiated units. Lacustrine unit: upper section composed of massive and grey marls (a) and detail of the peat level at the top of the unit and sampled for pollen analysis (BSB1) and radiocarbon dating $(41,190 \pm 210$ and 40,160 \pm 920 cal BP) (b). Fluvial unit: gravels showing cross-bedding and imbricated clasts at the bottom of the unit (c), laminated sediments affected by desiccation and bioturbation processes and small white saline masses (d) and charcoal level (14,360 $\pm 220 \mathrm{cal} \mathrm{BP})$ associated with in situ fires burning the sediments just below (e). Alluvial slope unit: silty gypsiferous sediments, including a small fireplace from the Late Roman Period (1540 \pm 80 cal BP) (f) and dispersed gypsum clasts filling a small channel $(\mathrm{g})$.

Figure 6. Palynological record obtained in lacustrine (BSB1: 41,190 \pm 210 cal BP) and fluvial (BSC3: 12,550 \pm 150 cal BP) units from Valsalada. The BSC3 pollen content was scarce with preservation of palynomorphs.

Table I. Radiocarbon ages of charcoal samples from Valsalada morphosedimentary units. Calibrated ages have been obtained using the CalPal program and the Intcal04 curve, excepting the two dates from the Lacustrine Unit that have been obtained using the CalPal2001 curve. 
This paper presents new data (geomorphlogical, sedimentological, palynological and radiocarbon data) from the Late Quaternary geological record of the Central Ebro Basin, which is the northernmost semiarid region in Europe. Our results indicate that the studied archives correspond to a sequence of depositional environments (lacustrine, fluvial and alluvial-slope) in a saline wetland system.

The palaeoenvironmental information derived from these data substantially improves the incomplete regional palaeoclimatic record for northeast Spain during the Late Pleistocene and Holocene. 

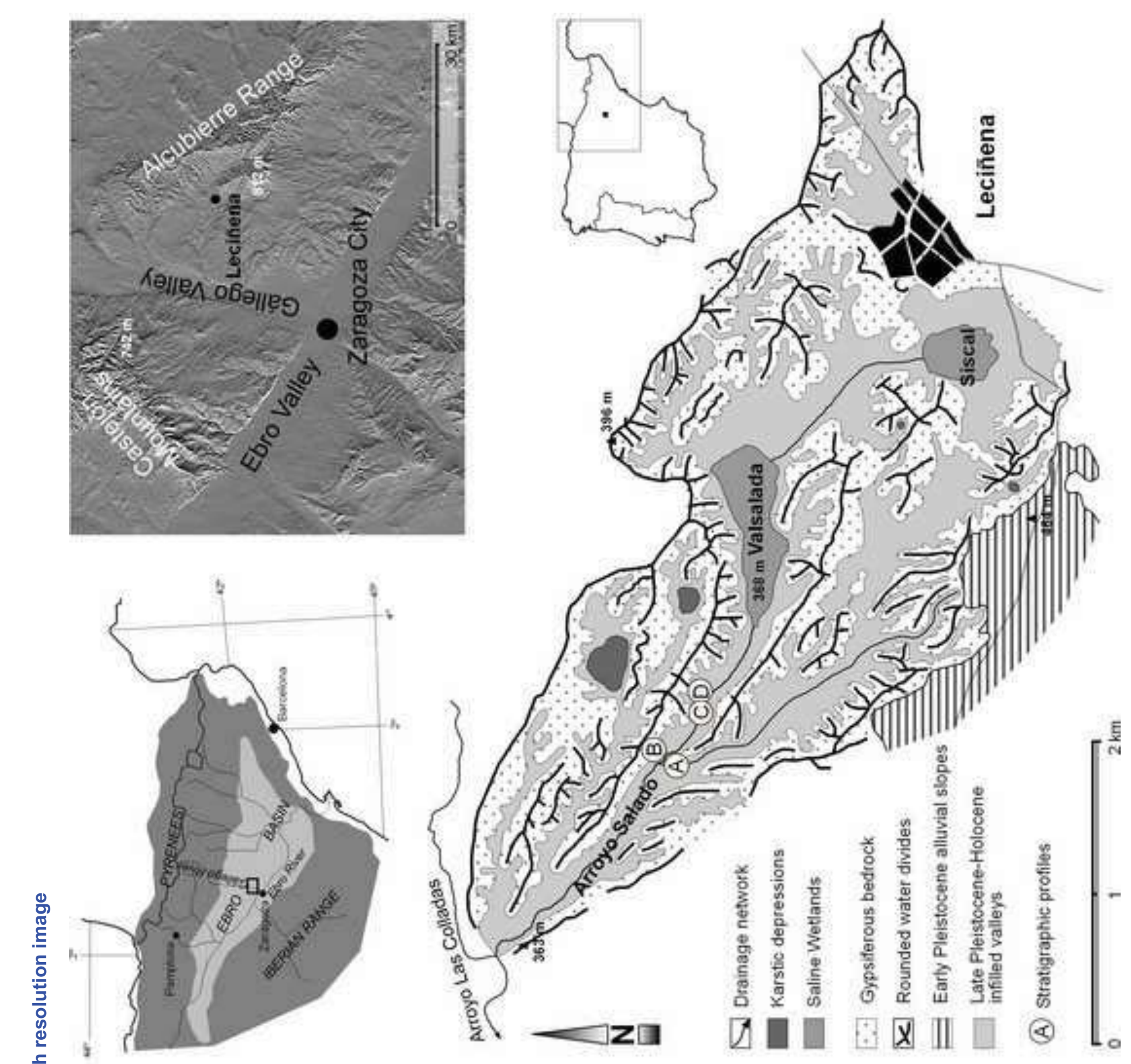


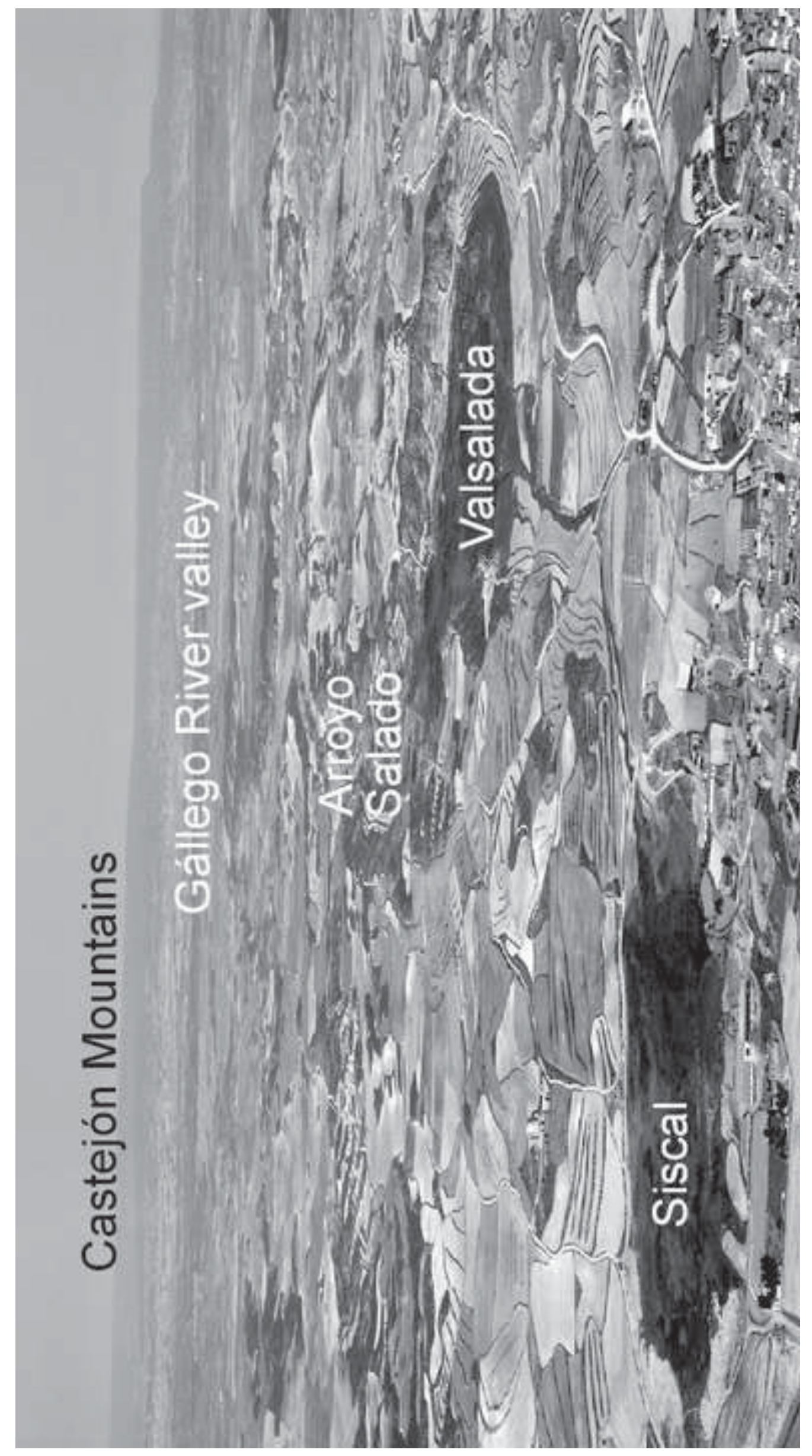



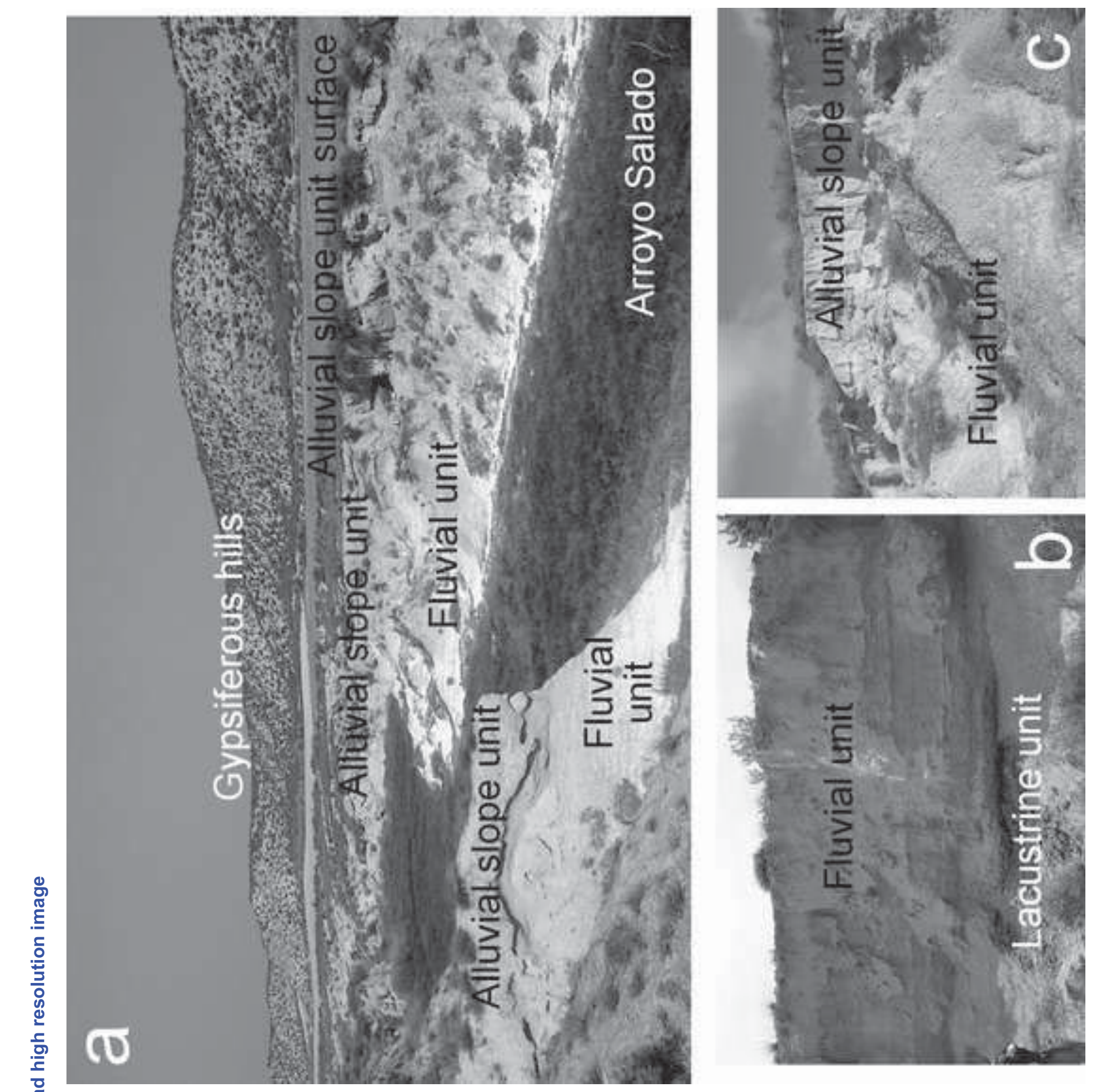


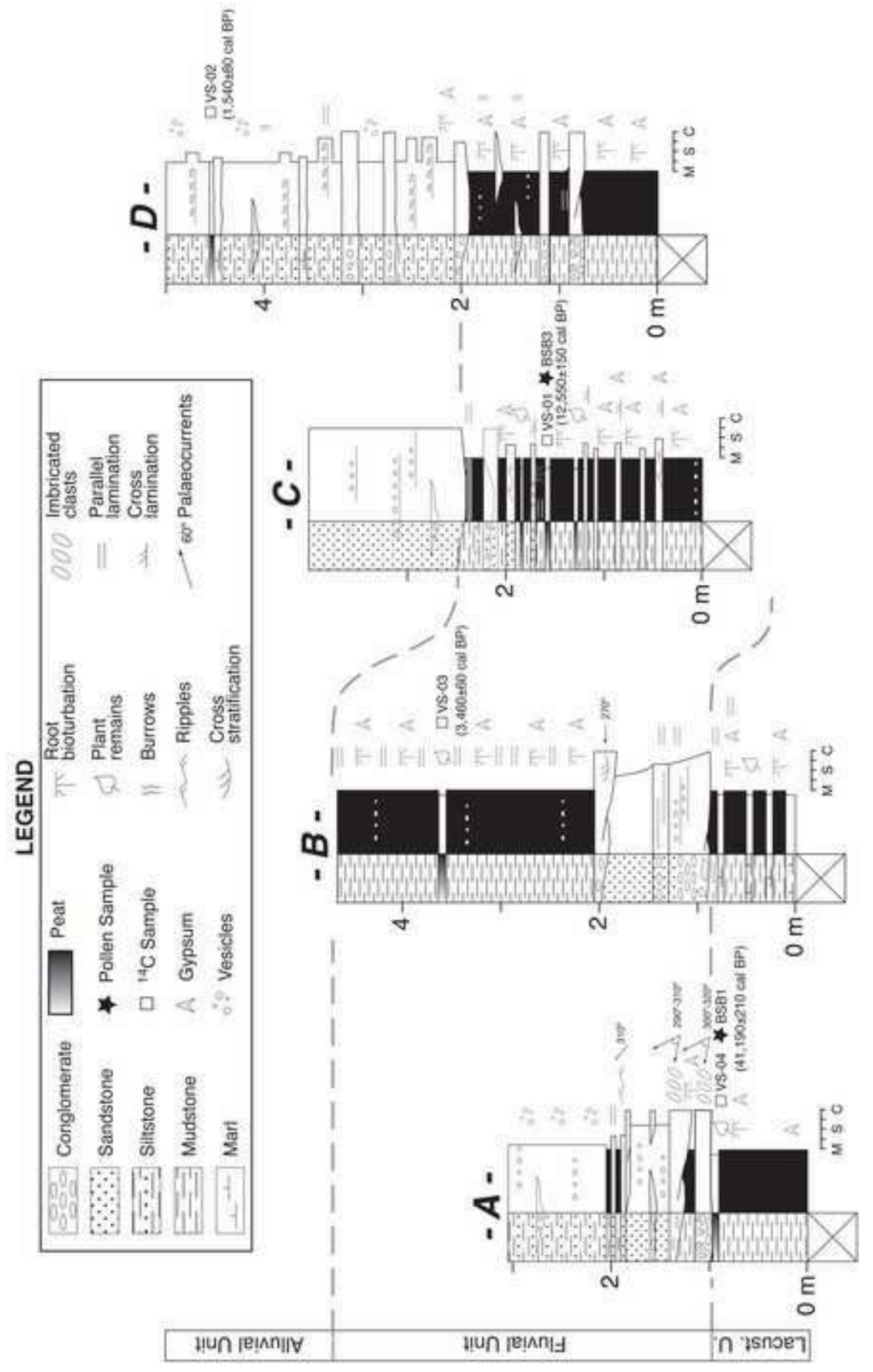




\section{Figure 5}

Click here to download high resolution image
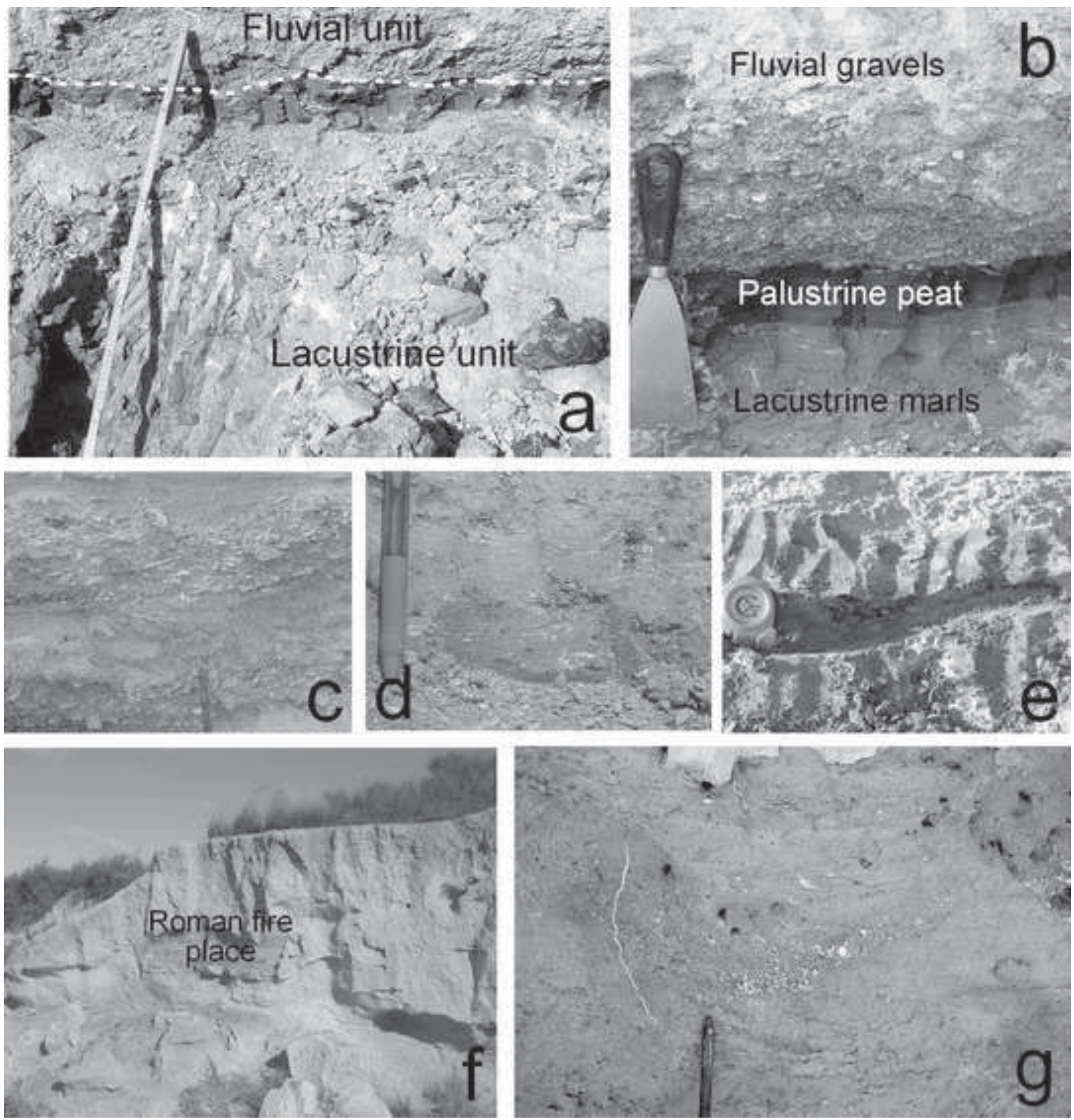


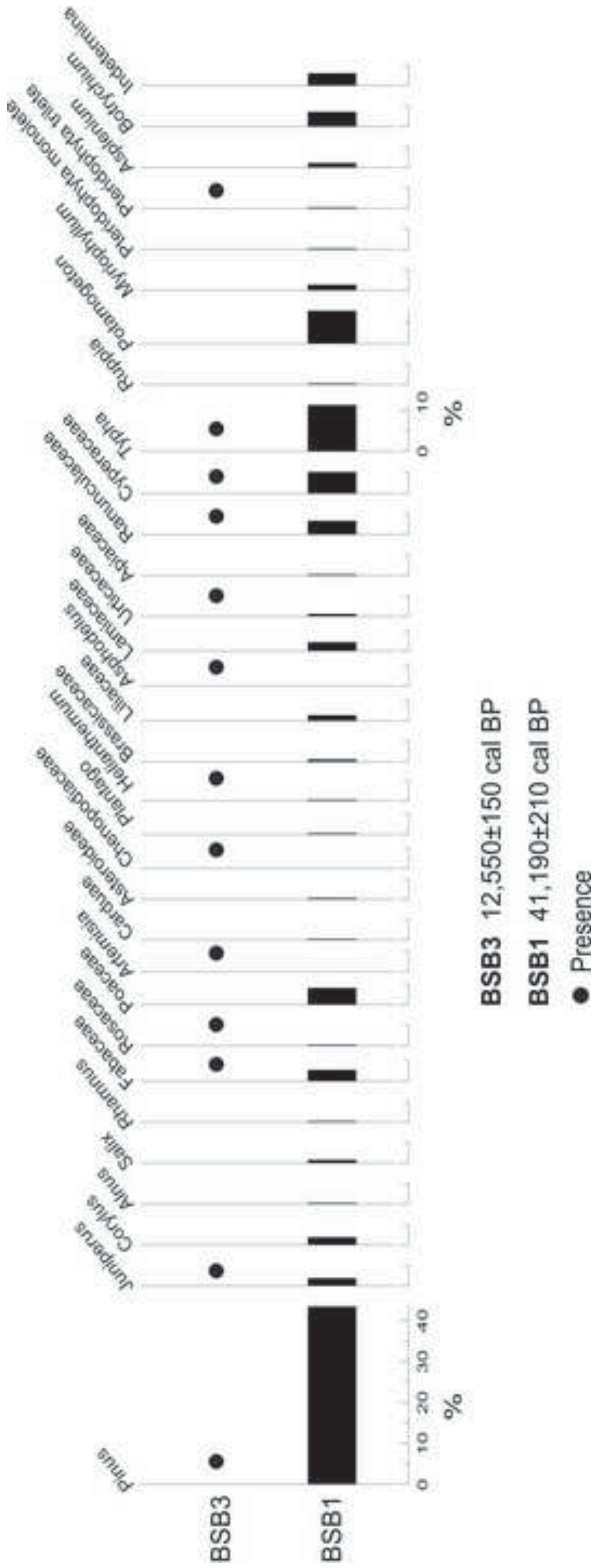




\begin{tabular}{|c|c|c|c|c|c|}
\hline Unit & Sample & $\begin{array}{c}\text { UTM Coordinates } \\
\text { (Longitude/Latitude) }\end{array}$ & Laboratory code & $\begin{array}{c}\text { Radiocarbon age } \\
\text { yr BP }\end{array}$ & $\begin{array}{c}\text { Calibrated age } \\
2 \sigma \text { yr BP }\end{array}$ \\
\hline Lacustrine & VS-04 & 30 T0694543/4632246 & UZ5236/ETH30926 & $37,050 \pm 550$ & $41,190 \pm 210$ \\
\hline Lacustrine & VS-06 & 30 T0694544/4632242 & UZ5526/ETH34410 & $36,170 \pm 730$ & $40,160 \pm 920$ \\
\hline Fluvial & VS-07 & 30 T0694544/462242 & UZ5527/ETH34411 & $12,330 \pm 90$ & $14,360 \pm 220$ \\
\hline Fluvial & VS-01 & 30 T0695103/4631926 & UZ5200/ETH30383 & $10,550 \pm 80$ & $12,550 \pm 150$ \\
\hline Fluvial & VS-05 & 30 T0693806/4633050 & UZ5310/ETH31865 & $5485 \pm 60$ & $6290 \pm 70$ \\
\hline Fluvial & VS-03 & 30 T0694483/4632320 & UZ5235/ETH30925 & $3225 \pm 50$ & $3460 \pm 60$ \\
\hline Alluvial slope & VS-02 & 30T0695315/4631787 & UZ5201/ETH30384 & $1640 \pm 50$ & $1540 \pm 80$ \\
\hline
\end{tabular}

